\title{
GUIDELINES FOR PROFESSIONAL TRAINING OF JUNIOR MEDICAL STAFF IN THE CONTEXT OF EUROPEAN EXPERIENCE
}

\begin{abstract}
The article deals with outlining guidelines for improving professional training of junior medical staff based on European experience. Consequently, guidelines and recommendations on enhancing the efficiency of medical education in general and junior medical specialists' professional training, in particular, published by European Union of Medical Specialists, General Medical Council, World Federation for Medical Education have been studied, analyzed, justified and presented in the paper. According to European Union of Medical Specialists it has been concluded that general aspects of medical specialists' training are based on the selection process for the access to the medical specialists' training, duration of training, common trunk, training program and quality assurance; requirements for training institutions involve recognition, size, quality assurance and teaching infructructure; requirements for instructors encompass qualification, training program, teacher/trainee ratio; requirements for trainees cover experience, language and logbook. In addition, the components that define the quality of junior medical specialists' professional training based on N. Novosolova's ideas have been indicated. Finally, based on the positive aspects of the guidelines analyzed the appropriate ones that, in our opinion, may be of use in Ukraine, have been presented.
\end{abstract}

Key words: guidelines, recommendations, professional training, medical specialists, junior medical specialist, medical school, European experience.

\section{INTRODUCTION}

The problem of improving scientific, theoretical and practical training of future medical specialists is one of the most topical in both national and international professional education. Modern society requires specialists able to easily adapt to rapidly changing social and technological conditions and use the obtained knowledge to solve professional issues. High-quality professional education involves the forming of the longterm knowledge and specialized skills to directly enter the labour market.

The needs to improve the quality of junior medical specialists' professional training and create conditions for their professional development are justified in the Laws of Ukraine "On the Approval of the National Program of Primary Health Care Development based on Family Medicine" (2010), "On the Amendments to the Basic Laws of Ukraine on Health Protection for Medical Services Enhancement" (2011), "The Conception of Establishing a New System of Health Protection in Ukraine" (2014), "The Code of Ethics of Nurses in Ukraine" (1999). Nevertheless, the desired quality of future junior medical specialists' professional training lacks scientifically justified pedagogical conditions for professional development.

Medical education is professional education, so its functioning and trends of development should not be reviewed in isolation from European and global context of 
higher education. Today, Europe seeks to create such a system of professional education that would meet the needs of each European country as well as the entire European region. So, the European integration process requires the unification of national systems of education in European space with common requirements, criteria and standards.

\section{THE AIM OF THE STUDY}

The aim of the paper consists in outlining guidelines for improving professional training of junior medical staff in Ukraine based on European experience.

\section{THEORETICAL FRAMEWORK AND RESEARCH METHODS}

Theoretical framework of the research is based on guidelines and recommendations on enhancing the efficiency of medical education in general and junior medical specialists' professional training, in particular, published by European Union of Medical Specialists, General Medical Council, World Federation for Medical Education.

Such methods as analysis, synthesis, systematization and generalizations have been used in the paper.

\section{RESULTS}

In Europe the search for common basic training of junior medical staff began in the mid 20th century. In 1968 Denmark, France, Germany, Greece and the United Kingdom signed the European Agreement on nursing education which established functional requirements to nurses, rules for admission to medical schools, the duration and content of theoretical and practical training (minimum 4600 hours or 3 years) (Гордійчук, Леонченко, 2011).

In 1988 in Scotland the World Federation of Medical Education held the World Conference on Medical Education, which resulted in the Edinburgh Declaration (World Federation for Medical Education, 1988). In the declaration for the first time in the history of medicine and medical school it was stated that traditional clinic-centric model of medical education did not involve the proper cultural and civilizational, social and environmental aspects and needs of humanity in the $21 \mathrm{st}$ century. The fundamental disadvantage of clinical-centric models in medical undergraduate and postgraduate education is the actual abandonment of familiarizing students with the real needs and interests of the population in the vast majority of countries. Thereby, the Edinburgh Declaration defined the steps of reforming medical education. They consist in the following:

1) the aim of professional training is to achieve professional competency;

2) the selection procedure of applicants should be based on their intellectual and other professional skills;

3) relevant and responsive learning environment;

4) the emphasis on preventing disease and promoting for health support;

5) medical practice throughout life;

6) professional training of medical schools teachers as both professionals and educators

7) integration of science and clinical practice;

8 ) correspondence of medical education to the needs of practical health protection;

9) cooperation between workers of the system of health protection multiprofessional education;

10) professional postgraduate lifelong learning (World Federation for Medical Education, 1988).

To improve the quality and efficiency of medical education in the European Union the recommendations on undergraduate medical education were published in 1993. These recommendations are supported by 93/16 Directive, adopted by the European Union Council: 
1) the primary purpose of undergraduate programs should be the forming of relevant knowledge, skills, attitudes and ethical values;

2) the curriculum should consist of two main parts, namely, basic and clinical sciences that can be integrated with each other;

3) basic medical sciences should be medically and practice-oriented as well as adapted to the needs of clinical training;

4) curricula and programs should not be overloaded;

5) teaching should be active;

6) core and elective courses of the curriculum should be regularly reviewed;

7) medical students should be encouraged to involved in the assessment of the curriculum and training programs;

8) clinical teaching should be carried out on campus and be chargeable;

9) medical education should focus on student-centered;

10) special attention should be paid to research methods, formulating and solving the fundamental and, in particular, clinical problems, based on a multidisciplinary approach;

11) European medical final examination and quality management of education system should be created (General Medical Council, 1993).

In 1994 the European Union of Medical Specialists adopted the "Charter on Training of Medical Specialists" to set the foundation for high-quality medical training. It contains main principles for high-level medical training and outlines major criteria for medical training programmes and curricula. It must be noted that the Charter is regularly updated so that the continuing development of medical practice may be ensured.

Thus, general aspects of medical specialists' training include the selection process for the access to the medical specialists' training, duration of training, common trunk, training program as well as quality assurance.

First of all, teachers or training institutions are to select and appoint those trainees suitable for the specialty. This selection process must be transparent and equal for all those who have obtained basic medical training.

The duration of the training should be adequate for obtaining core professional competences and further peofessional activity. Training should by preference be full-time. Concerning part-time programs the National Authority should approve an individually tailored program. In addition, all trainees should have training in administration, management and economics of specialized medicine. Training should take place following an established programme with specified contents approved by the National Authority in accordance with national rules and EU legislation as well as considering EUMS/ European Board recommendations. The different stages of training and the activities of the trainee should be recorded in a training logbook.

The National Authority as well as the instructors and medical educational establishments must introduce a policy on the assurance of the training quality. Attendance of training institutions by the National Authority should be carried out in a structured way. The National Authority is to regulate the access to training according to national manpower planning projects in the EU countries.

Requirements for medical schools involve recognition, size, quality assurance and teaching infructructure. Thereby, medical institutions must be approved by the National Authority. Trainees must be trained in approved medical schools and institutions in other EU member countires during their training by the approval of their training programme by the National Authority of the country of origin. National Authorities may recognize training in non-EU countries. 
The medical schools must have an internal system of quality assurance including such features as mortality conferences, reporting of accidents in agreement with a structured procedure. Moreover, various hospital activities in the field of quality control such as infection control and drugs and therapeutics committees must exist.

In the institution, the trainee should have space and opportunities for practical and theoretical study. Access to adequate national and international professional literature should be provided as well as space and equipment for practical training of techniques in a laboratory setting.

Requirements for instructors encompass qualification, training program, teacher/ trainee ratio. The chief of training should have been practising the specialty for at least 5 years after specialist accreditation or should have completed a specific training programme before recognition as such. There should be additional teaching staff. The chief of training and the staff should be practising the specialty in its full extent. Sub specialized teachers may be recognized by the National Authority for periods during the training.

The training programme for each trainee should be structured in accordance with national rules and EC legislation as well as considering UEMS/European Board recommendations. The ratio between the number of qualified specialists on the teaching staff and the number of trainees should provide close personal monitoring of the trainee during his/her training and provide adequate exposure of the trainee to the training.

Requirements for trainees cover experience, language and logbook. So, to build up his/her experience, the trainee should be involved in the treatment of a sufficient number of outpatients (ambulatory) and inpatients and perform an adequate number of procedures of sufficient diversity. In addition, the trainee should have sufficient linguistic ability to communicate with patients and to study international literature and communicate with foreign colleagues. Also, the trainee should keep his/her personal log-book or equivalent up to date according to national rules and EC Directives as well as considering UEMS/European Board recommendations.

According to N. Novosolova the quality of junior medical specialists' professional training depends on many components, namely, a) marketing of the education institution, including modern forms of career guidance with young people, using modern methods for selecting students, motivating students for cognitive activity; 2) the social status of the nursing profession in society today; 3 ) the level of students' social protection, novelty and topicality of the curricula and training programs; 4) the availability of clear, specific and understandable education standards for diagnosing the level of knowledge and skills of students as well as the competence of graduates; 5) the use of active and developmental methods and innovative learning technologies; 6) the quality of scientific and methodological support of the educational process; 7) learning facilities; 8) the level of informatization of the educational process; 8) democratization, humanization, personalization and differentiation of the educational process; 9) provision of practical training with clinical bases; 10) the level of teaching staff training; 11) the level teachers' motivation; 12) the effective training control; 13) skilled and effective management of medical schools; 14) the correspondence of medical education to the requirements of the global educational space, etc. (Новосьолова, 2007).

It should be noted that the reforming of junior medical specialists' professional training has its achievements. Thus, in 2007 the All-Ukrainian Congress "The Development of Nursing in Ukraine" was held at the Bukovynskyi State Medical University. As a result, the Ministry of Health Protection of Ukraine introduced the position of a deputy of chief nursing officer and the functional responsibilities for the position were approved. 
In order to improve the system of junior medical specialists' continuous training and to enhance medical assistance to Ukrainian population the Ministry of Health Protection of Ukraine established and approved "Regulations on Nurse-Coordinator of Health Care Establishments" (Гордійчук, Леонченко, 2011).

\section{CONCLUSIONS}

So, based on the above we can conclude that in Europe there are many recommendations and guidelines for medical education developed and published to improve the professional training of medical specialists and, in particular, junior medical specialists and thus enhance the level of medical assistance Mostly, they include requirements to medical institutions, teaching staff and trainees and are regularly updated to correspond to existing needs. In their turn, European medical institutions follow these recommendations and strive for sustainable development that can be proved by internationally recognized achievements of European medicine as a field and European medical specialists.

Based on the positive aspects of the guidelines analyzed we have outlined appropriate ones that, in our opinion, may be of use in Ukraine. So, they are: 1) to develop and implement curricula and training programs for junior medical specialists based on European well-established models; 2 ) to regularly monitor the curriculum so that it may correspond to the existing needs of national and international scope; 3 ) to regularly monitor core professional competencies of medical staff, instructors at medical schools, in particular; 4) to involve medical students in monitoring quality of curricula and training programs; 5) to implement the latest information and innovative educational technologies into the educational process at medical schools; 6) to pay special attention to the forming of future junior medical specialists' technical competency.

We believe it necessary to profoundly study the principles of training in patient safety in European countries, in Denmark, in particular.

\section{REFERENCES}

1. European Union of Medical Specialists. (2013). European Standards in Medical Training. Retrieved 8.10.2016 from : https://www.uems.eu/areas-of-expertise/postgraduatetraining/european-standards-in-medical-training.

2. General Medical Council. (1993). Tomorrow's Doctors: Recommendations on Undergraduate Medical Education. Retrieved 9.10.2016 from : http://www.gmc-uk.org/10a annex_a.pdf 25398162.pdf.

3. World Federation for Medical Education. (1988). The Edinburgh Declaration. Retrieved 9.10.2016 from : http://wfme.org/projects/wfme-publications/99-the-edinburghdeclaration/file.

4. World Federation for Medical Education. (1988). World Conference of Medical Education Report. Edinburgh : World Federation for Medical Education, 8 p.

5. Гордійчук, С. В., Леонченко, Н. П. (2011). Європейський та український досвід підготовки кадрів для медсестринства [European and Ukrainian Experience in Training Nurses]. Наукові записки Тернопільського національного педагогічного університету ім. В. Гнатюка. Серія: Педагогіка [Scientific Notes of V. Gnatyuk Ternopil National Pedagogical University ], No 4, pp. 195- 200 (in Ukrainian).

6. Новосьолова, Н. Ф. (2007). Проблема якості медичної освіти у Свропейському освітньому просторі [The Problem of Medical Education Quality in the European Education Space]. Медсестринство [Nursing], No 1, pp. 16-20 (in Ukrainian). 